\title{
LAYANAN BIMBINGAN KELOMPOK UNTUK MENURUNKAN STRES AKADEMIK MAHASISWA FKIP UNIVERSITAS HALU OLEO
}

\author{
oleh: \\ Alber Tigor Arifyanto \\ Dosen Jurusan Bimbingan dan Konseling/FKIP UHO \\ Email: tigoralber@uho.ac.id
}

\begin{abstract}
ABSTRAK
Penelitian ini bertujuan mengetahui apakah bimbingan kelompok dapat mengurangi stress akademik mahasiswa FKIP Universitas Halu Oleo. Jenis penelitian ini adalah pre eksperimen dengan desain one group pre-test and post-test. Subyek penelitian ini berjumlah 11 mahasiswa. Hasil analisis deskriptif persentase menunjukkan bahwa skor rata-rata stres akademik mahasiswa sebelum diberikan layanan bimbingan kelompok sebesar 83,27 atau 69,39\% yang berada pada kategori tinggi. Setelah diberikan layanan bimbingan kelompok mengalami penurunan sebesar 13,45 sehingga menjadi 69,82 atau $58,18 \%$ yang berada pada kategori rendah. Hasil analisis inferensial data stres akademik diuji menggunakan Wilcoxon signed rank dengan taraf signifikan $\alpha=0,05$ diperoleh $\mathrm{P}_{\text {value }}=0,002 . \mathrm{P}_{\text {value }}<\alpha(0,002<0,05)$. Dengan demikian $\mathrm{H}_{\mathrm{a}}$ diterima yang berarti layanan bimbingan kelompok dapat menurunkan stress akademik mahasiswa FKIP Universitas Halu Oleo.
\end{abstract}

\section{Kata Kunci: Stres Akademik, Layanan Bimbingan Kelompok}

\section{PENDAHULUAN}

Mahasiswa merupakan individu yang berada pada masa remaja akhir. Hal ini sebagaimana dikemukakan oleh Deswita (2006: 192) mengenai batasan usia remaja yang umum digunakan oleh para ahli adalah antara 12 hingga 21 tahun. Rentang waktu usia remaja ini biasanya dibedakan atas tiga, yaitu remaja awal antara usia 12 - 15 tahun, remaja pertengahan antara usia $15-18$ tahun dan dan masa remaja akhir antara usia 18 - 21 tahun. Sedangkan Monks, Knoers, dan Haditono (dalam Deswita, 2006) membedakan masa remaja menjadi empat bagian, yaitu masa praremaja 10 - 12 tahun, masa remaja awal 12 - 15 tahun, masa remaja pertengahan 15 - 18 tahun, dan masa remaja akhir 18 - 21 tahun.
Pada masa remaja akhir ini perubahan yang terjadi terdiri dari proses berpikir, perubahan sosial, gejolak emosional dan minat individu terhadap hal-hal baru. Perubahanperubahan yang terjadi tersebut perlu mendapatkan perhatian yang lebih, mengingat masa ini juga disebut dengan masa kritis. Masa kritis dimaksud adalah masa dimana terjadinya perubahan tekanan baik secara sosial dan akademis yang mengharuskan mahasiswa memiliki peran dan tanggungjawab yang berbeda dari periode sebelumnya.

Masa perkuliahan yang dikenal dengan sebagai masa penuh tekanan yang ditandai dengan adanya tuntutan perkuliahan yang melebihi kapasitas dapat menimbulkan stres, termasuk yang dialami oleh mahasiswa. Transisi 

dikarakteristikkan sebagai peristiwa kehidupan yang penuh dengan tekanan karena terjadi berbagai perubahan hidup. Beberapa orang lebih sensitif terhadap tekanan yang dihadapi daripada yang lain sehingga karakteristik seseorang dan pola perilaku harus dilihat untuk menentukan kepentingan dan kerentanan mereka terhadap stres. Banyak mahasiswa mengalami stres yang amat tinggi terkait dengan tuntutan perkuliahan yang sangat tinggi seperti banyaknya tugas-tugas yang harus diselesaikan. Desmita (2010) mengatakan bahwa stress akademik merupakan respon peserta didik terhadap tuntutan sekolah yang menekan dan menimbulkan perasaan tidak nyaman, ketegangan dan perubahan perilaku. Stress akademik ini merupakan respon yang muncul karena terdapatnya ketegangan yang disebabkan oleh tuntutan akademik yang harus dikerjakan atau dilakukan oleh individu.

Jika stress akademik yang dialami oleh mahasiswa tidak dapat dikendalikan atau diatasi akan mempengaruhi pikiran, perasaan, reaksi fisik, dan tingkah lakunya. Seperti: a) secara kognitif (pikiran), kesulitan memusatkan perhatian dalam belajar, sulit mengingat pelajaran atau mudah lupa, sulit memahami bahan pelajaran, berpikir negatif pada diri dan lingkungannya; b) secara afektif, munculnya rasa cemas, sensitif, sedih, kemarahan, frustasi; c) secara fisiologis, muka memerah, pucat, lemah dan merasa tidak sehat, jantung berdebardebar, gemetar, sakit perut, pusing, badan kaku dan berkeringat dingin; d) dampak tingkah laku yang muncul antara lain merusak, menghindar, membantah, berkata kotor, menghina, menunda-nunda penyelesaian tugas sekolah, malas ke kampus, dan terlibat dalam kegiatan mencari kesenangan secara berlebih-lebihan dan beresiko.

Fenomena stress akademik juga dialami oleh mahasiswa Fakultas keguruan dan Ilmu Pendidikan (FKIP) Universitas Halu Oleo. Menurut pengamatan dan interaksi langsung peneliti dengan mahasiswa ditemukan berbagai masalah yang mengindikasikan jika mahasiswa mengalami stress akademik seperti kehilangan konsentrasi, muncul perilaku penghindaran diri dengan teman-teman di kampus, melakukan penundaan dalam menyelesaikan tugastugas, ketidakhadiran dalam perkuliahan, yang pada akhirnya dapat berdampak negatif terhadap prestasinya.

Salah cara yang dapat digunakan bagi mahasiswa untuk mengatasi stres akademik adalah dengan memberikan layanan bimbingan kelompok dianggap tepat untuk menurunkan stress akademik karena dalam bimbingan kelompok pimpinan kelompok menyediakan informasiinformasi, dan mengarahkan diskusi agar anggota kelompok menjadi lebih sosial atau untuk membantu anggota kelompok mencapai tujuan-tujuan bersama seperti memerolehh solusi terhadap suatu permasalahan yang dialami serta dengan mendapatkan dukungan dari anggota kelompok. Yang artinya semua peserta dalam kegiatan kelompok saling berinteraksi, bebas mengeluarkan pendapat, menanggapi, memberikan saran dan lain-lain. Semua yang dibahas dalam kelompok diharapkan memberikan manfaat bagi seluruh peserta (Wibowo, 2005: 17). Dalam bimbingan kelompok anggota kelompok berlatih mengemukakan ide, perasaan, pendapat, menambah 
kepercayaan diri, mengembangkan keterbukaan dan bertukar pikiran melalui dinamika kelompok yang berlangsung selama kegiatan kelompok.

Tujuan penelitian ini adalah untuk mengetahui apakah bimbingan kelompok dapat menurunkan stress akademik mahasiswa FKIP Universitas Halu Oleo.

\section{Definisi Stress Akademik}

Stres adalah reaksi psikologis seseorang terhadap tantangan dalam hidup yang membebani kehidupan seseorang dan tidak sesuai dengan harapan seseorang tersebut sehingga mengganggu kesejahteraan hidup (Mumpuni \& Wulandari, 2010). Stres akademik merupakan respon peserta didik terhadap tuntutan sekolah yang menekan yang menimbulkan perasaan tidak nyaman, ketegangan dan perubahan tingkah laku. Stres akademik merupakan Desmita (2010).

Stres akademik adalah stres yang muncul karena adanya tekanan- tekanan untuk menunjukkan prestasi dan keunggulan dalam kondisi persaingan akademik yang semakin meningkat sehingga mereka semakin terbebani oleh berbagai tekanan dan tuntutan. Stres akademik yang dialami mahasiswa merupakan hasil persepsi yang subjektif terhadap adanya ketidaksesuaian antara tuntutan lingkungan dengan sumber daya aktual yang dimiliki siswa (Agista, 2011).

Berdasarkan beberapa pendapat diatas dapat disimpulkan bahwa stres akademik merupakan suatu respon yang muncul yang ditimbulkan oleh stimulus-stimulus berupa tuntutan akademik yang menimbulkan ketegangan, perasaan tidak nyaman dan perubahan perilaku. Stres ini muncul karena adanya ketidak sesuaian antara tuntutan lingkungan dengan sumber daya aktual yang dimiliki oleh individu mahasiswa sehingga ia merasa semakin terbebani oleh berbagai tekanan atau tuntutan akademik.

\section{Aspek-aspek yang Memengaruhi Stres Akademik}

Sun, Dunne dan Hou (2011) mengemukakan lima aspek stres akademik yaitu:

\section{Tekanan Belajar}

Tekanan belajar berkaitan dengan tekan yang dialami individu ketika sedang belajar di sekolah dan di rumah. Tekanan yang dialami oleh individu dapat berasal dari orang tua, teman sekolah, ujian di sekolah serta jenjang pendidikan yang lebih tinggi.

\section{Beban Tugas}

Beban tugas berkaitan dengan tugas yang harus dikerjakan oleh individu di kampus. Beban yang dialami individu berupa pekerjaan rumah, tugas-tugas dan ujian-ujian.

\section{Kekhawatiran Terhadap Nilai}

Aspek intelektual berkaitan dengan kemampuan seseorang untuk memperoleh ilmu pengetahuan baru. Aspek ini juga berkaitan dengan proses kognitif individu. Individu yang sedang mengalami stres akademik akan sulit untuk berkonsentrasi, mudah lupa dan terhadap penurunan kualitas kerja.

\section{Ekspektasi Diri}

Ekspektasi diri berkaitan dengan kemampuan seseorang untuk memiliki harapan atau ekspektasi terhadap 
dirinya sendiri. Seseorang yang memiliki stres akademik akan memiliki ekspektasi yang rendah terhadap dirinya sendiri seperti merasa selalu gagal dalam nilai akademik dan merasa selalu mengecewakan orang tua dan guru apabila nilai akademis tidak sesuai dengan yang diinginkan.

\section{Keputusasaan}

Keputusasaan berkaitan dengan respon emosional seseorang ketika ia merasa tidak mampu mencapai target/tujuan dalam hidupnya. Individu yang mengalami stres akademik akan merasa bahwa dia tidak mampu memahami pelajaran serta mengerjakan tugas-tugas di kampus.

Aspek stress akademik yang dikemukakan oleh Sun, Dunne dan Hou (2011), yang terdiri dari tekanan belajar, beban tugas, kekhawatiran terhadap nilai, ekspektasi diri dan keputusan akan dijadikan peneliti sebagai rujukan dalam mengembangkan instrumen penelitian.

\section{Definisi Bimbingan Kelompok}

Tohirin (2013: 170) menyebutkan bahwa bimbingan kelompok adalah suatu cara memberikan bantuan kepada individu melalui kegiatan kelompok. Dalam bimbingan kelompok, aktivitas dan dinamika kelompok harus diwujudkan untuk membahas berbagai hal yang berguna bagi pengembangan atau pemecahan masalah individu yang menjadi peserta.

Selanjutnya Nurihsan (2016: 23) menyatakan bimbingan kelompok merupakan bantuan terhadap individu yang dilaksanakan dalam situasi kelompok. Bimbingan kelompok dapat berupa penyampaian informasi ataupun aktifitas kelompok yang membahas masalah-masalah pendidikan, pekerjaan, pribadi dan sosial. Bimbingan kelompok dapat berupa penyampaian informasi atau aktivitas kelompok membahas masalah-masalah pendidikan, pekerjaan, pribadi, dan masalah sosial.

Berdasarkan penjelasan di atas dapat disimpulkan bahwa bimbingan kelompok adalah bimbingan kelompok adalah suatu kegiatan yang dilakukan secara berkelompok yang dimaksudkan untuk mencegah berkembangnya masalah atau kesulitan pada diri konseli/klien. Isi kegiatan bimbingan kelompok terdiri atas penyampaian informasi yang berkenaan dengan masalah pendidikan, pekerjaan, pribadi, dan masalah sosial yang tidak disajikan dalam bentuk pelajaran.

\section{Tujuan Pelaksanaan Bimbingan Kelompok}

Tohirin (2013: 172) mengemukakan secara umum tujuan bimbingan kelompok adalah mengembangkan kemampuan bersosialisasi khususnya kemampuan berkomunikasi siswa. Lebih khusus tujuan layanan bimbingan kelompok adalah mendorong pengembangan perasaan, pikiran, persepsi, wawasan dan sikap yang menunjang perwujudan tingkah laku yang lebh efektif, yakni peningkatan kemampuan berkomunikasi baik verbal maupun non verbal para siswa.

Winkel dan Hastuti (2015: 519) mengemukakan bahwa tujuan umum diadakannya bimbingan kelompok adalah untuk membina proses dalam kelompok. Bimbingan kelompok juga mempunyai tujuan meningkatkan profesionalisme tenaga bimbingan. 
Sedangkan tujuan khusus bimbingan kelompok adalah bimbingan kelompok bermaksud membahas topik-topik tertentu yang mengandung permasalahan aktual, dan menjadi perhatian peserta. Melalui dinamika kelompok yang intensif.

\section{Tahapan Pelaksanaan Bimbingan Kelompok}

Prayitno (2004:18) mengemukakan tahapan layanan bimbingan kelompok diselenggarakan melalui empat tahap kegiatan yaitu a) tahap pembentukan, b) tahap peralihan, c) tahap kegiatan dan d) tahap pengakhiran.

\section{METODE PENELITIAN}

Penelitian ini telah dilaksanakan selama tiga bulan mulai bulan September Oktober 2019. Penelitian ini bertempat di FKIP Universitas Halu Oleo. Pemberian Treatment berupa Layanan Bimbingan Kelompok dilaksanakan sebanyak 5 kali pertemuan dengan durasi waktu tiap pertemuan selama $2 \mathrm{x}$ 45 menit.

Jenis penelitian yang digunakan dalam penelitian adalah penelitian eksperimen dengan menggunakan metode pre-eksperimen dengan desain one group pretest-posttest design.

Rancangan penelitian disajikan pada bagan berikut.

Bagan 3.1. Desain Penelitian (one group pretest-posttest design)
$\mathbf{O}_{1}$
$\mathbf{X}$
$\mathbf{O}_{2}$

$$
\begin{aligned}
& \text { Keterangan: } \\
& \mathrm{O}_{1}=\text { Pre test, untuk mengukur }
\end{aligned}
$$

Penelitian ini mengambil subyek sebanyak 11 orang mahasiswa FKIP Universitas Halu Oleo. Pemilihan subyek penelitian ditentukan berdasarkan pertimbangan:

1. Subyek penelitian dipilih berdasarkan skor pengukuran angket stress akademik. Dengan kriteria mendapatkan skor skor tinggi pada angket stress akademik.

2. Subyek penelitian yang terpilih mendapatkan rekomendasi dari ketua jurusan masing-masing.

3. Subyek penelitian mau dan bersedia bekerjasama untuk mengikuti kegiatan bimbingan kelompok.

4. Subyek penelitian tidak memeroleh intervensi lain yang sama dengan intervensi pada penelitian ini.

Penelitian ini terdiri dari dua variabel yaiti layanan bimbingan kelompok sebagai variabel bebas dan stres akademik sebagai variabel terikat.

Data dalam penelitian ini dikumpulkan dengan menggunakan angket yaitu angket angket stres akademik. Angket stres akademik tersebut disusun oleh peneliti dengan jumlah soal sebanyak 43 butir pernyataan. 
Data penelitian dianalisis dengan menggunakan analisis statistik deskriptif presentase untuk mendapatkan data skor rata-rata variabel stress akademik dan dengan menggunakan analisis statistik inferensial untuk menjawab hipotesis penelitian. Data dianalisis dengan bantuan aplikasi SPSS Versi 18.

\section{HASIL DAN PEMBAHASAN}

\section{Hasil dan Pembahasan}

1. Berdasarkan analisis data dapat dilihat secara keseluruhan terjadi penurunan skor stres akademik mahasiswa. Perbandingan skor stres akademik subyek penelitian dapat dilihat pada tabel berikut.

Tabel 1. Perbandingan Skor Pre-test dan Skor Post-test Stres Akademik Mahasiswa

\begin{tabular}{|c|c|c|c|c|c|c|c|c|}
\hline \multirow[b]{2}{*}{ No } & \multirow{2}{*}{ Responden } & \multicolumn{2}{|c|}{ Pre-test } & \multirow{2}{*}{ Kategori } & \multicolumn{2}{|c|}{ Post-Test } & \multirow{2}{*}{ Kategori } & \multirow{2}{*}{ Penurunan } \\
\hline & & Skor & $\%$ & & Skor & $\%$ & & \\
\hline 1 & $\mathrm{R} 1$ & 79 & 65,83 & Tinggi & 66 & 55,00 & Rendah & 13 \\
\hline 2 & $\mathrm{R} 2$ & 99 & 82,50 & $\begin{array}{l}\text { Sangat } \\
\text { Tinggi }\end{array}$ & 77 & 64,17 & Tinggi & 22 \\
\hline 3 & R3 & 83 & 69,17 & Tinggi & 70 & 58,33 & Rendah & 13 \\
\hline 4 & $\mathrm{R} 4$ & 81 & 67,50 & Tinggi & 68 & 56,67 & Rendah & 13 \\
\hline 5 & R5 & 85 & 70,83 & Tinggi & 76 & 63,33 & Tinggi & 9 \\
\hline 6 & R6 & 79 & 65,83 & Tinggi & 66 & 55,00 & Rendah & 13 \\
\hline 7 & R7 & 81 & 67,50 & Tinggi & 68 & 56,67 & Rendah & 13 \\
\hline 8 & R8 & 88 & 73,33 & Tinggi & 75 & 62,50 & Rendah & 13 \\
\hline 9 & R9 & 82 & 68,33 & Tinggi & 69 & 57,50 & Rendah & 13 \\
\hline 10 & R10 & 82 & 68,33 & Tinggi & 69 & 57,50 & Rendah & 13 \\
\hline 11 & R11 & 77 & 64,17 & Tinggi & 64 & 53,33 & Rendah & 13 \\
\hline & ata-rata & 83,27 & 69,39 & Tinggi & 69,82 & 58,18 & Rendah & 13,45 \\
\hline
\end{tabular}

Berdasarkan tabel 2 di atas terlihat bahwa setelah diberikan layanan bimbingan kelompok seluruh subyek penelitian mengalami penurunan stres akademik dengan skor rata-rata sebesar 13,45

2. Hasil uji Wilcoxon signed rank test data stress akademik mahasiswa FKIP Universitas Halu Oleo dapat dilihat pada tabel 2 dibawah ini.
Tabel 2. Hasil Pengujian Data Stres Akademik dengan Uji Wilcoxon

\begin{tabular}{lr}
\multicolumn{1}{c}{ Test Statistics $^{\mathbf{a}}$} \\
& \multicolumn{2}{c}{$\begin{array}{l}\text { Post_Test - } \\
\text { Pre_test }\end{array}$} \\
\hline & $-3.125^{\circ}$ \\
\hline Asymp. Sig. (2-tailed) & .002 \\
\hline $\begin{array}{l}\text { a. Wilcoxon Signed Ranks Test } \\
\text { b. Based on positive ranks. }\end{array}$ &
\end{tabular}

Berdasarkan data pada tabel 4 di atas, terlihat bahwa nilai $\mathrm{z}_{\text {hitung }}$ sebesar 3,125 dengan nilai $\mathrm{P}_{\text {value }}$ (Asymp. Sig. (2-tailed)) sebesar 0,002. Karena nilai

$\mathrm{P}_{\text {value }}<\alpha \quad(0,002<0,05)$, maka hipotesis yang diterima adalah $\mathrm{H}_{\mathrm{a}}$ yang berarti pemberian layanan bimbingan 
kelompok dapat menurunkan stres akademik mahasiswa.

Dari data stres akademik dapat disimpulkan bahwa hipotesis $\mathrm{H}_{\mathrm{a}}$ diterima yang berarti "pemberian layanan bimbingan kelompok dapat menurunkan stress akademik mahasiswa FKIP Universitas Halu Oleo".

\section{KESIMPULAN DAN SARAN}

\section{Kesimpulan}

1. Sebelum pemberian layanan bimbingan kelompok, skor stres akademik berada pada kategori tinggi dengan skor sebesar 83,27 atau $69,39 \%$.

2. Setelah diberikan layanan bimbingan kelompok skor stres akademik mahasiswa mengalami penurunan sebesar 13,45 menjadi 69,82 atau $58,18 \%$ berada pada kategori rendah.

3. Hasil analisis data pre-test dan posttest stres akademik diperoleh nilai

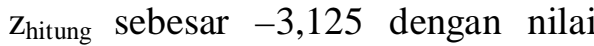
$\mathrm{P}_{\text {value }}$ (Asymp. Sig. (2-tailed)) sebesar 0,002 . Karena nilai $\mathrm{P}_{\text {value }}<\alpha \quad(0,002$ $<$ 0,05), maka hipotesis yang diterima adalah $\mathrm{H}_{\mathrm{a}}$ yang berarti pemberian layanan bimbingan kelompok dapat menurunkan stres akademik mahasiswa.

4. Dari analisis data stres akademik dapat disimpulkan bahwa hipotesis $\mathrm{H}_{\mathrm{a}}$ diterima yang berarti "layanan bimbingan kelompok dapat menurunkan stress akademik mahasiswa".

\section{Saran}

1. Bagi jurusan agar mengaktifkan layanan konseling yang ada pada setiap jurusan, sehingga dapat membantu mahasiswa yang mengalami berbagai masalah seperti masalah stress akademik mahasiswa yang berpotensi dialami oleh mahasiswa dan dapat mengganggu kinerja akademik selama menempuh perkuliahan.

2. Bagi para dosen dapat menjadikan kegiatan kelompok seperti bimbingan kelompok sebagai salah satu alternatif dalam membantu mahasiswa menurunkan stres akademik pada semua mahasiswa dan khususnya bagi mahasiswa yang berada pada semester akhir dan dalam penyusunan skripsi.

3. Bagi mahasiswa, bimbingan kelompok tidak hanya dapat dilakukan dengan bimbingan dosen atau profesinal saja, namun dapat dilakukan oleh sesama mahasiswa melalui bentuk bimbingan teman sebaya.

\section{DAFTAR PUSTAKA}

Agista, Isni. 2011. Penanganan Kasus Stres Dalam Menghadapi Aktivitas Kuliah Melalui Pendekatan Konseling Behavioristik Dengan Teknik Pengelolaan Diri Pada Mahasiswa Jurusan Seni Rupa FBS UNNES, (Semarang, 2011) hal. 78-80.

Azmy, A. N., Achmad J. N. dan Eka S.Y. Deskripsi Gejala Stres Akademik dan Kecenderungan Pilihan Strategi Koping Siswa Berbakat. Indonesian Journal Of Educational Counseling. Volume 1, No. 2, hal. 197-208. Juli 2017.

$\begin{array}{cr}\text { Desmita. } 2010 . & \text { Psikologi } \\ \text { PerkembanganPeserta } & \text { Didik. }\end{array}$ 
Bandung: PT Remaja

Rosdakarya.

Deswita. 2006.

Perkembangan. Bandung:

Remaja Rosdakarya.

Devito. J. A. 2011. Komunikasi Antar Manusia Edisi Kelima. Alih Bahasa: Ir. Agus Maulana, M.S.M. Tangerang: Karisma Publishing Group.

Hidayat, D. 2012. Komunikasi Antar Pribadi dan Medianya. Yogyakarta: Graha Ilmu.

Mumpuni, Yekti dan Ari Wulandari. 2010. Cara jitu mengatasi stress. Yogyakarta: Andi.

Nurihsan, A. Juntika, 2016. Bimbingan dan Konseling : Dalam Berbagai Latar dan Kehidupan. Bandung: Rineka Cipta.

Nurmaliyah, $\quad$ Faridah. 2014. Menurunkan Stres Akademik Siswa dengan Menggunakan Teknik Self-Instruction. Journal Pendidikan Humaniora. Vol.02 No.03, Hal.273-282, September 2014.

Prayitno. 2004. L.6-L.7. Layanan Bimbingan Kelompok dan Konseling Kelompok. Padang : Jurusan Bimbingan dan Konseling Universitas Negeri Padang.

Sari, Giyono dan Rahmayanti. 2016. Upaya Meningkatkan Selfdisclosure dengan Menggunakan Bimbingan Kelompok pada Siswa. Jurnal Bimbingan dan Konseling.

Sun, J, Dunne, MP, Hou, Xiang-Yu \& $\mathrm{Xu}$, Ai-Qiang. (2011). Educational Stress Scale for Adolescent. Journal of psychoeducational Assesment.
Diakses pada tanggal 7 Maret 2016 dari http://dx.doi.org/.

Tohirin, 2013. Bimbingan Konseling di Sekolah dan Madrasah. Jakarta: Raja Grafindo Persada.

Wibowo, Mungin Edi. 2005. Konseling Kelompok Perkembangan. Semarang: Unnes Press.

Winkel, W.S. dan Hastuti. 2015. Bimbingan dan Konseling di Institusi Pendidika: Edisi Revisi. Jakarta: Gramedia.

Yusuf, Syamsu. 2011. Psikologi perkembangan anak dan remaja. Bandung: PT Remaja Rosdakaryam. 